\title{
Decision of Constitutional Court on the Rights of the Child Out of Wedlock
}

\author{
Bambang Ali Kusumo ${ }^{1}$ Abdul Kadir Jaelani ${ }^{2}$ Dora Kusumastuti ${ }^{3}$ \\ ${ }^{1.3}$ Faculty of Law, Universitas Slamet Riyadi \\ ${ }^{2}$ Faculty of Law, Universitas Sebelas Maret \\ Surakarta, Indonesia \\ alikusumobambang@yahoo.co.id
}

\begin{abstract}
The status of children in Indonesia has been regulated in various laws and regulations. In marriage law, it is defined that a legitimate child is a child born from or in a legal marriage. However, after the issuance of the Constitutional Court's decision on the status of children out of wedlock, a debate arose among legal academics and practitioners of Islamic law in Indonesia. This debate is quite challenging and does not clear up the problem. This article aims to discuss the status of children out of wedlock after the issuance of the Constitutional Court. This article is a literature study, and the data were collected by investigating regulations and decisions regarding the status of children. This article argues that the constitutional court's decision establishes a new norm, which revises the rule of article 43 in the marriage law. According to the constitutional court's decision, children born out of wedlock have a civil relationship not only from the mother's line but also from the father's line on the condition that they can be proven biologically and scientifically.
\end{abstract}

Keywords- Child out of Wedlock, Marriage, Constitutional Court.

\section{INTRODUCTION}

There are four ways to consider a child's lineage in Islamic law: (1) Pregnancy is not impossible for a wife, implying that pregnancy is normal and natural. Hanafi holds that this is not required, even if the husband and wife do not have sexual relations. The child is legitimate if it is born to a legally married woman. (2) At least six months after the marriage is performed. This is the shortest period of pregnancy, according to Islamic jurisprudence experts. (3) the child is born before the gestation period is completed. Islamic law experts continue to disagree on this point. (4) through the li'an institution, the husband does not deny the child. If a man has doubts that the minimum limit for pregnancy has not been met or that the maximum limit for pregnancy has been exceeded, then the husband has a reason to deny the child conceived by his wife through li'an [1].

In this issue, Islamic law experts concur with Anwar Al Amrusy's assertion that there is no legal unity in bloodline. After all, Islamic law is extremely concerned with the benefit and protection of children born legally and children born outside of marriage, both of whom should be protected because the child is not a sinner; the sinners are his parents. This viewpoint is understandable because the lineage problem discussed in fiqh books is based on what is proven and visible physically, not on hidden aspects of a person [2].

A genuine child occupies a unique status within his family. Parents are obligated to provide a means of subsistence, a sufficient education, and to maintain the child's existence until he or she is an adult and capable of earning a living on his or her own. A kid born of a lawful marriage has a well-defined status on his or her rights, which includes inheritance. Legitimate children are a source of hope for their parents, who are also the descendants' successors [3].

A valid child, as defined in Article 42 of the Marriage Law, is one born during or as a result of a legitimate marriage, whereas a legitimate marriage, as defined in Article 1 paragraph (2) of the 1974 Marriage Law, is one conducted in accordance with the laws of their respective religions and beliefs. A legitimate child, as defined in the two preceding sections, is a kid born in a valid marriage according to the husband and wife's religion and beliefs, or a child born as a consequence of marriage according to the husband and wife's religion and beliefs [4] [5].

When examined closely, it becomes clear that there is an inconsistency between the textual meaning of Article 2 paragraph (2) of Marriage Law and its contextual implementation. If Article 42 of the 1974 Marriage Law defines a legitimate child as one born during or as a result of a legitimate marriage, the issue of a child's legitimacy should not be linked to the registration of marriage, as marriage registration does not imply that the marriage is valid [6]. However, marriages that are legally performed according to religious law but not registered following Article 2 paragraph (2) of Marriage Law will result in the birth of children with the status of children born outside of marriage, as is the case with sirri marriages. A legitimate child is defined by law as one born or born as a result of a marriage that is registered or recorded at the marriage registrar's office, as a sirri marriage is religiously a legitimate marriage. It will result in the birth of an illegitimate child in practice [7]. The Marriage Law's explanation for section 4 letter $\mathrm{b}$ states as follows:

According to this law, a marriage is valid if it is performed under the laws of religion and belief; additionally, every marriage is equivalent to 
recording significant events in a person's life, such as birth and death, in certificates, an official document that is also included in the register.

According to the explanation above, those who perform marriages are required to keep records. However, the explanation makes no mention of the fact that failure to comply with the registration obligation will result in the marriage's invalidity, as stated in Article 2 paragraph (1) of the Marriage Law, which is the domain of religious law and the bride and groom's trust. The substance of recording a marriage is a form of administrative obligation on the part of a citizen to ensure that a legal action deemed to have legal consequences for the parties receives legal protection from the State as an institution that supersedes all of its citizens' interests [8].

While Article 43 paragraph (1) of the Marriage Code states that "a child born outside of marriage has only a civil relationship with his mother and her family," the sound of the article above also lends itself to numerous interpretations. Outside Marriage is defined as a birth that occurs without a marriage ceremony, for example, a child born in adultery, or it is also included in the definition of an illegitimate marriage based on religious law, as required by Article 2 paragraph (1) of the Marriage Law, or it refers to a legally recognized marriage that is not registered under Article 2 paragraph (1) of the Marriage Law (2) [9]. Each of the three scenarios outlined above presents a unique set of legal difficulties. If the term is intended to refer to a scenario in which no marriage has occurred, then a kid born from that marriage may not be considered a legitimate child because it is a child born of adultery without prior marriage, but if the term is intended to refer to a child born during or as a result of marriage, then the child born from that marriage may be regarded as a legitimate child. If a marriage is legally lawful but not registered, it should not be categorized as an unmarried child, and so the phrasing of Article 43 paragraph (1) of the Marriage Law is inapplicable, as marriage and registration are two distinct concepts, even if one influences the other [10].

The issue of children born outside of marriage is one that must be resolved, as the impact of these issues is not only legal, but also social, which might jeopardize the life of children born outside of legitimate marriage.

\section{FINDINGS AND DISCUSSION}

Following the judge's determination, this decision elicited a response from a variety of circles. Not only on a normative and philosophical level, but also on a practical level in various judicial institutions throughout Indonesia, most notably in the Religious Courts. According to some, the decision will result in legal changes that will improve the protection of children's rights. Meanwhile, other public opinion has developed an understanding that the Constitutional Court's decision will result in numerous complications, and the new complications have altered Islamic law [11].
This controversy is inextricably linked to Indonesian society's strong tradition of Islamic law. Inevitably, the Constitutional Court's judgment conflicts with a number of legal provisions currently in place in Indonesia, both by the government and religious institutions. A kid born outside of marriage has no other connection than that of kinship with his or her mother and family. This is referred to as a legitimate child, which is defined as a kid born outside the womb as a consequence of a legal marriage and fertilization of a husband and wife [12]. The Compilation of Islamic Law allows for the integration of children born as a consequence of a pregnant woman's marriage into a legal child, even if the kid is born just a few days after the marriage [13]. According to Compilation of Islamic Law (KHI), a child born outside of marriage to a man who is not his legal husband according to Islam and the law is not inheritable, and the child has a kinship relationship with his mother but not with his father, and is not entitled to a living. And his father's care. According to the MUI fatwa, children born of adultery had no kinship, inheritance, or living relationship with their mother or her family [14].

It must be acknowledged that the everyday practice of law shows the presence of legal plurality, since there are groups of individuals who strictly adhere to religious law in their daily civil interactions or who strictly adhere to local customary law in their daily civil connections. The 1945 Constitution controls and rigorously safeguards this legal diversity, as long as it does not violate the objectives of the Unitary State of the Republic of Indonesia [15]. Conflicts between national law, religious law, and customary law practices are inevitable as a consequence of legal pluralism [16].

The state cannot theoretically compel the implementation of religious norms or beliefs because religious norms or beliefs are a private transcendental belief domain, specifically the relationship between humans and their creators [17]. By contrast, in this case, UUP, legal norms are provisions made by the state as a manifestation of citizens' (society's) agreement with the state, allowing the state to enforce it (government). The potential losses associated with marriages that do not adhere to the UUP for women (wives) are numerous, but what matters is whether or not these losses are recoverable. This is a critical point of the UUP, particularly in relation to the regulation governing marriage registration [18].

According to some groups, the decision No. 46/PUUVIII/2010 is a rule that protects children's rights. This is true. This decision allows for the acceptance of the child's interests and rights that he should have received from his biological father. No child born on this planet should be blamed or discriminated against on the basis of his or her parents' act or manner of marriage. Among the various responses that have emerged, the most influential is that of the Indonesian Ulema Council (MUI), which is a wellestablished institution that represents Indonesian Muslims [19]. The MUI issued Fatwa No. 11 of 2012 in 2010 in response to the decision No. 46/ PUU-VIII/2010 
regarding the Position of Children Resulted in Adultery and Treatment Against It. The primary reason for the existence of this MUI fatwa is that the Constitutional Court's decision is contentious because it allows for the possibility of a civil relationship between an adulterous child and the man who caused his birth. According to Islamic law, the civil relationship refers to lineage, inheritance, maintenance, and guardianship, and thus the Constitutional Court's decision is interpreted as opening the door to the legalization of adultery [20].

In response to various criticisms of the decision, most notably from the Indonesian Ulema Council, the Constitutional Court issued an official statement or explanation clarifying that the Court did not intend to legalize adultery. According to the Constitutional Court, the decision is not about legality of marriage but about protecting children's civil rights, and thus It is critical to recognize that child protection and the problem of adultery are two different legal systems. In this regard. Apart from the Constitutional Court's opinion, Mahfud MD did not personally confirm the view that became the focal point of the debate during a single interview [21]. $\mathrm{He}$ believes that the Constitutional Court's decision to conduct a judicial review of the Marriage Law is intended to curtail the spread of adultery. The Constitutional Court's judges decided the case with an eye toward avoiding adultery. Men will undoubtedly be fearful of committing adultery in the future as a result of the possibility of legal liability [22].

Additionally, Akil Mochtar11 stated that the Constitutional Court's decision was made solely to provide civil protection for a child born out of wedlock to his biological father, even though the marriage's validity is still being contested. The Constitutional Court's decision must be applied carefully by judicial institutions, both general and religious, in determining whether there is a blood or legal relationship between fathers and children born out of wedlock. The Marriage Law and the decision of the Constitutional Court are merely general legal rules (lex generalis) governing the status and position of children [23]. Meanwhile, other rules (lex specialis) are more specific, such as the Civil Code and the Law on Religious Courts, which are supplemented by the Compilation. Protection of children outside of marriage must be proportionate, which means adhering to applicable laws and regulations, as well as local customs, without jeopardizing applicable religious law [24].

The Constitutional Court's decision should not be interpreted as a justification for extramarital relations and is not inconsistent with Articles 1 and 2 of Law No. 1 of 1974. In terms of inheritance, civil rights cannot be realized through the concept of Islamic inheritance, but rather through the concept of Another illustration is the concept of compulsory will [25]. Similarly, those relating to a child's living or living expenses are not manifested in the child's living according to Islamic law, but rather through other forms of obligation on the biological father in the form of punishment to pay a certain amount of money or assets for the child's living or living expenses until adulthood. Children and succession The Constitutional Court's decision should not be interpreted as a justification for extramarital relations and is consistent with Articles 1 and 2 of Law No. 1 of 1974 [26].

In terms of inheritance, civil rights cannot be realized through an Islamic concept of inheritance but through other concepts, such as the concept of mandatory will. Similarly, those relating to a child's living or living expenses are not manifested in the child's living according to Islamic law, but rather through other forms of obligation on the biological father in the form of punishment to pay a certain amount of money or assets for the child's living or living expenses until adulthood. Adolescents and heirs [27].

\section{CONCLUSION}

The legal regulation governing the position of children born without marriage, acknowledged by Constitutional Court Decision 46/PUU-VIII/2010, explains their position. This Supreme Court decision establishes a legal basis for a child's civil relationship with his biological father. Previously, the situation of children born out of wedlock was recognized. Paragraph 1 of UUUP 43 is not self-contained. Article 2 of Marriage Law No. 1 of 1974 defines marriage. The Constitutional Court's judgment creates civil rights related with inheritance rights. The rule controlling the inheritance of children born out of wedlock is recognized by civil law. Children receive a valid acknowledgment of their inheritance rights from their parents. Although the constitutional court's decision provides the legal basis for determining the child's legal status based on biological and scientific evidence, this decision does not address the question of whether the biological father died prematurely. Thus, one could argue that the legal consequence of Constitutional Court Decision No. explaining that establishing paternity for a child born out of wedlock through DNA testing is not always possible. This decision is therefore not immediately applicable in a real-world judicial environment.

\section{REFERENCES}

[1] I. H. Hasibuan, S. Saidurrahman, and A. A. Tarigan, "Inheritance Rights for Adultery Children; an Analysis of Proserity Approach to The Inheritance Rights for Adultery Children in The Islamic Law Compilation," Int. J. Lang. Res. Educ. Stud., vol. 3, no. 3, pp. 351-363, 2019.

[2] M. Masyhur, "Status Anak Dari Perkawinan Dibawah Tangan Pasca Putusan Mahkamah Konstitusi Nomor 46/Puu-Viii/2010 Tanggal 17 Februari 2012 Ditinjau Dari Peraturan PerundangUndangan," JISIP (Jurnal Ilmu Sos. dan Pendidikan), vol. 4, no. 4, 2020, doi: 10.36312/jisip.v4i4.1469.

[3] A. Farahi and R. Ramadhita, Keadilan Bagi Anak 
Luar Kawin dalam Putusan Mahkamah Konstitusi Nomor 46/PUU-VIII/2010, vol. 8, no. 2. Maulana Malik Ibrahim State Islamic University of Malang, 2017.

[4] Syahlan, "Effective and Efficient Synchronization in Harmonization of Regulations Indonesia," vol. 1, no. 1, pp. 54-70, 2021.

[5] H. Asnawi, "Politik Hukum Putusan MK No. 46/PUU-VIII/2010 Tentang Status Anak Di Luar Nikah: Upaya Membongkar Positivisme Hukum Menuju Perlindungan HAM," J. Konstitusi, vol. 10, no. 2, pp. 239-260, 2013.

[6] R. Res, "Implementation of Parate Executie Object of Liability Juridical Overview of Mortgage," vol. 1, no. 1 , pp. 42-53, 2021.

[7] A. R. Habibi, "The Dynamics Of Illegitimate Child Status In Sharia And National Law Of Indonesia: Is There A Harmonization?," Al-Manhaj J. Indones. Islam. Fam. Law, vol. 3, no. 1, pp. 70-80, 2021.

[8] A. S. Cholis, "the Legal Standing \& Inheritance Rights for Out-of-Wedlock Child in Relation To the Constitutional Court'S Decision in Terms of Civil Inheritance Law," Audit. Comp. Law J., vol. 1, no. 2, pp. 71-77, 2020, doi: 10.22219/audito.v1i2.13759.

[9] A. K. Jaelani and R. D. Luthviati, "The Crime Of Damage After the Constitutional Court's Decision Number 76/PUU-XV/2017," J. Hum. Rights, Cult. Leg. Syst., vol. 1, no. 1, pp. 2807-2812, 2021, doi: 10.53955/jhcls.v1i1.5.

[10] R. A. G. Purwasaputri, S. Sudarsono, and M. Fadli, "Fulfillment of the Principle of Justice in Making Birth Certificates for Children Born Outside of Legal Marriage Between Both Parents," Int. J. Multicult. Multireligious Underst., vol. 8, no. 7, p. 259, 2021, doi: 10.18415/ijmmu.v8i7.2837.

[11] M. J. Hayat, "Historisitas dan Tujuan Usia Minimal Perkawinan dalam Perundang-undangan Keluarga Muslim Indonesia dan Negara Muslim," J. Equitable, vol. 3, no. 1, pp. 49-63, 2018.

[12] M. Jamil, "Fiduciary Security Arrangements and Issues in Indonesia," J. Hum. Rights, Cult. Leg. Syst., vol. 1, no. 2, pp. 109-119, 2021, doi: 10.53955/jhcls.v1i2.1.

[13] S. Djazimah and M. J. Hayat, "Pelaksanaan Kursus Pranikah Di Kota Yogyakarta: Urgensitas, Efektivitas Hukum, Dan Tindakan Sosial," Al-Ahwal J. Huk. Kel. Islam, vol. 11, no. 1, p. 59, 2019, doi: 10.14421/ahwal.2018.11105.

[14] T. T. Tutik, "Implications of the Verdict of Constitutional Court Number 46/PUU-VIII/2010 on the Hereditary Right of Illegitimate Children Born of Mixed Couple in Islamic Law Perspective," SSRN Electron. J., 2013, doi: 10.2139/ssrn.2297279.

[15] F. U. Najicha, "Oil and Natural Gas Management Policy in Realizing Equal Energy in Indonesia," $J$. Hum. Rights, Cult. Leg. Syst., vol. 1, no. 2, pp. 7179, 2021, doi: 10.53955/jhcls.v1i2.8.

[16] A. Ma'ruf, "Legal Aspects of Environment in Indonesia : an Efforts to Prevent Environmental
Damage and Pollution," vol. 1, no. 1, pp. 18-30, 2021.

[17] G. T. Sekotibo, "The Strength of Evidence (Certificate) in Land Rights Disputes According to Government Regulation No. 24 of 1997 Concerning Land Registration," J. Hum. Rights, Cult. Leg. Syst., vol. 1, no. 2, pp. 120-130, 2021, doi: 10.53955/jhcls.v1i2.12.

[18] H. Habibah, "STATUS KEWARISAN ISLAM ANAK LUAR NIKAH: Pasca Putusan Mahkamah Konstitusi No. 46/PUU-VIII/2010," Moderation| J. Islam. Stud. Rev., vol. 1, no. 1, pp. 81-90, 2021.

[19] Iswantoro, "Strategy and Management of Dispute Resolution, Land Conflicts at the Land Office of Sleman Regency," vol. 1, no. 1, pp. 1-17, 2021.

[20] T. Hamidah, "Constitutional court verdict number 46/PUU-VIII/2010, dated February 17, 2012 from women leaders perspective," 2013, [Online]. Available: http://repository.uin-malang.ac.id/5252/.

[21] A. Ma'ruf, "Application of Timber Legality Verification System (SVLK) Policy as Ecolabel Implementation in the Indonesian Timber Industry," J. Hum. Rights, Cult. Leg. Syst., vol. 1, no. 2, pp. 92-99, 2021, doi: 10.53955/jhcls.v1i2.10.

[22] H. Hamam, "The Status of Outside Marriage Children (The Study of Constitutional Court Regulation No. 46/PUU-VIII/2010 on February 27th, 2012 Based on the Fuqaha' Perspective)," Int. J. Educ. Res. Soc. Sci., vol. 2, no. 3, pp. 574-584, 2021, doi: 10.51601/ijersc.v2i3.85.

[23] S. D. Baranyanan, "Simplification of Law Regulations in Copyright Criminal Act Settlement," J. Hum. Rights, Cult. Leg. Syst., vol. 1, no. 2, pp. 80-91, 2021, doi: 10.53955/jhcls.v1i2.9.

[24] Marilang, "Legal relationship between illegitimate children and their biological father the analysis of constitutional court decree no. 46/PUU-VIII/2010 in the perspective of civil and islamic law," J. Indones. Islam, vol. 10, no. 2, pp. 335-354, 2016, doi: 10.15642/JIIS.2016.10.2.335-354.

[25] A. A. Herman and M. J. Hayat, "Management of High Secondary Education After Regional Government Law," J. Hum. Rights, Cult. Leg. Syst., vol. 1, no. 2, pp. 395-396, 2021, doi: 10.53955/jhcls.v1i2.11.

[26] Cok Gede Mega Putra, "Civil Relationship of Children Born without Marriage with Biological Father based on Constitutional Court Decision Number 46/PUU-VIII/2010," NOTARIIL J. Kenotariatan, vol. 5, no. 2, pp. 58-64, 2020, doi: 10.22225/jn.v5i2.2585.

[27] H. E. Saputra, I. Zaki, and M. U. Al Mustofa, "Constitutional Court Decision Number 46 / PuuViii / 2010 Reviewed from the Perspective of Adat Law, Burgerlijk Wetboek (Bw) and Islamic Law," pp. 660-663, 2019, doi: $10.5220 / 0007549006600663$. 